УДК 373.2:616.89-008.434.37

DOI: $10.28925 / 2311-2409.2021 .3514$

\title{
Сулятицький І.,
}

голова Центру психоінформації,

доцент кафедри спеціальної освіти та соціальної роботи

Львівського національного університету імені Івана Франка,

кандидат психологічних наук, доцент

sulo@ukr.net

ORCID iD 0000-0002-3769-5630

\section{Порохнява А.,}

студентка кафедри спеціальної освіти та соціальної роботи (бакалавр)

Львівського національного університету імені Івана Франка

nastyalapaivka@gmail.com

ORCID iD 0000-0003-4728-2028

\section{ЕМОЦІЙНО-ВОЛЬОВІ ОСОБЛИВОСТІ ДОШКІЛЬНИКІВ ІЗ ДИСЛАЛІЄЮ}

У статmі здійснено аналіз теоретичних основ та емпіричних взаємозв'язків між емоційно-вольовими особливостями й мовним порушенням (дислалією) у дітей дошкільного віку. Узагальнено дослідження емоційно-вольової сфери дошкільників з дислалією та дошкільників, мовлення яких не має відхилень від норми. За результатами емпіричного вивчення на основі встановлених зв'язків між рівнем розвитку емоційно-вольової сфери та порушеннями мовлення у дітей дошкільного віку визначено сприятливі фактори ефективних корекційних прийомів відновлення нормативних емоційно-вольових параметрів вікової динаміки у дошкільників.

Ключові слова: емочії, воля, дислалія, мовлення, загальний недорозвиток мовлення, нерізко виражений недорозвиток мовлення, фонетичний недорозвиток мовлення, фонетико-фонематичний недорозвиток мовлення.

(с) Сулятицький І., Порохнява А., 2021

( ) Київський університет імені Бориса Грінченка, 2021

Вступ. Сьогодні щороку зростає кількість дітей із порушеннями мовленнєвого розвитку, і все більше суспільство стає зацікавленим у надаванні їм якісної психокорекційної допомоги. Одним із найбільш поширених мовленнєвих порушень у дітей дошкільного віку є дислалія.

Сформованість мовлення є однією з найважливіших складових гармонійності дитячої особистості. Нетиповий його розвиток може призвести до того, що дитина матиме неправильну вимову, а при більш складних формах порушень зазнає деформацій ціла низка структур психіки: мислення, пам'ять, увага й особливо емоційно-вольова сфера. Розвиток останньої $€$ дійсно важливим у сучасному світі, де все більше уваги приділяється рівню розвитку так званого емоційного інтелекту та вмінь самоконтролю. Адже саме ці фактори виступають запорукою гармонійного формування особистості та подальшої іï реалізації у суспільстві.

Метою статті $€$ визначення особливостей емоційно-вольової сфери дітей дошкільного віку з дислалією.
Завдання статті полягають у здійсненні теоретичного аналізу наукових напрацювань з окресленої проблематики; проведенні емпіричного вивчення специфіки емоційно-вольових процесів у дошкільників $з$ дислалією, визначенні взаємозв'язків між рівнем розвитку емоційновольової сфери та порушеннями мовлення у дітей дошкільного віку.

Аналіз сучасних досліджень. Попри те, що проблематика емоційно-вольової сфери особистості розглядалася у дослідженнях П. Анохіна, П. Мілнера, П. Фресса, Д. Ліндслі, В. Вундта, В. Джемса, Г. Ланге, В. Квін, С. Рубінштейна та ін., до сьогодні не існує одностайності в поясненні емоцій, не кажучи вже про їх стале розуміння у віковій динаміці дитинства. Так, наприклад, П. Анохін у теорії функціональних систем розглядає емоції як компонент різноманітних стадій цілеспрямованих поведінкових актів різної складності [5, с. 4]. Своєю чергою, П. Мілнер, а за ним і П. Фресс, стверджував, що хоч й існує певна градація відчуттів від слабких до сильних, та лише 
сильні переживання можна назвати емоціями. На думку науковців, емоції - це ті переживання, від яких людина втрачає контроль, які заважають iii адаптації. Подібне розуміння емоцій виражене в активаційній теорії Д. Ліндслі, згідно з якою їх поява супроводжується погіршенням діяльності, яку виконує людина [5, с. 6-7].

Цікаву думку висловив В. Вундт про те, що емоції - це насамперед внутрішні зміни, яким притаманний безпосередній вплив почуттів на перебіг уявлень. «Тілесні» реакції науковець розглядає лише як наслідок почуттів [3, с. 438]. Однакової думки щодо емоцій були В. Джемс та Г. Ланге. Вони вважали, що певні фізіологічні реакції зумовлюють появу емоцій, «...тому найраціональніше висловлюватися так: ми засмучені, тому що плачемо; розлючені, тому що б'ємо іншого; боїмося, тому що тремтимо» [4, с. 464].

Сьогодні емоціями вважаються психічні стани людини, у яких реалізується безпосереднє ситуативне переживання останньою тих явищ та ситуацій, які впливають на неї [19, с. 96]. За словами В. Квін, «емоції - це суб'єктивне ставлення людини до світу, пережите як задоволення або незадоволення потреб. Ці почуття можуть бути приємними, неприємними й змішаними. Люди дуже рідко переживають емоції в чистому вигляді» [3, с. 438].

Стосовно волі як психічної якості також існує багато цікавих теорій, проте більшість вчених дотримується приблизно схожої думки. Наприклад, К. Левін вважає, що воля - це така поведінка, яка спирається на джерела енергії не природних, а квазіпотреб, тобто уявних потреб. Д. Узнадзе наголошував на тому, що основою для такої поведінки є певні установки, які іiі цілеспрямовують і впорядковують [3, с. 604]. Найбільш класичним $є$ визначення волі як психічного процесу свідомої регуляції людиною своєї діяльності та поведінки з метою досягнення певної цілі [8, с. 150].

Якщо говорити про порушення емоційновольової сфери дітей дошкільного віку, то слід зазначити, що вольовий контроль своєї діяльності їм дається доволі важко. Крім того, дошкільний вік є сензитивним періодом для формування мовлення та корекції мовних порушень. Цьому сприяють такі особливості дошкільників, як висока пластичність мозку, здатність все перетворювати на гру, що сприяє більш швидким досягненням і в корекційній роботі; прагнення до оволодіння звуками і неміцність помилкових мовних навичок [11].

Порушення мовлення у ранньому дитинстві співвідповідні психічному і фізичному розвитку дитини, але згодом вони можуть викликати труднощі у контакті з оточуючими. Вже з 4-5 років більш розвинені діти помічають недоліки свого мовлення і часто болісно це переживають [12, с. 19].
Одним із найпоширеніших порушень мовлення $є$ дислалія. Дислалія - це порушення вимовної (звукової) сторони мовлення при збереженій іннервації мовленнєвого апарата та нормальному слуху [14, с. 54].

У $80-\mathrm{x}$ роках $\mathrm{XX}$ ст. австрійський лікар Коен у своїх роботах намагався класифікувати дислалії. Наприкінці XIX - початку XX ст. 3'являються дослідження зарубіжних авторів: Куссмауля, Гуцмана, Фрешельс, Лібмана, Земана та ін., які розглядають проблему недорікуватості [14, с. 50].

Російський лікар Є. Борішпольска ще у 1921 р. розділила розлади мови на дві групи - центральні та периферичні. До центральних вона зараховувала функціональну афазію та недоліки органічного походження (заїкання і белькотання). До периферичної - дислалію або алалію. Серед дислалії (алалії) виділяла такі розлади, як глухонімота, пов'язана з ураженням вуха, і недорікуватість. Автор вважала, що остання залежить тільки від недосконалості артикуляційного апарату [12, с. 34].

Безумовно, порушення мовлення мають вплив на психічний розвиток дитини, оскільки, за влучним висловлюванням С. Коноплястої, мовлення прямо пов'язане з мисленням [10].

Слід зазначити, що дислалія не має особливого впливу на психічний розвиток дитини. Однак якщо це акустико-фонематична чи артикуляторно-фонематична iі форми, то у дитини можлива нестійка увага, що призводить до погіршення запам'ятовування матеріалу, легкого відволікання, більшої кількості помилок.

У дітей з дислалією, як стверджує О. Бєлова, емоційна сфера та характер страждають лише у деяких випадках, проте супроводжуються роздратованістю, плаксивістю, розгальмованістю та агресивністю [1, с. 304].

Процедура та результати дослідження. Вивчення особливостей емоційно-вольової сфери дітей дошкільного віку з дислалією проведені на базі закладу дошкільної освіти № 37 «Струмочок» (м. Львів). У дослідженні брали участь діти старшого дошкільного віку. Досліджувана група складалася з 41 особи, з них контрольна група - 30 дітей, 11 - діти із дислалією. Вік: 5-6 років. Для визначення рівня емоційно-вольового розвитку дітей дошкільного віку проводилися такі методики: «Вибери потрібне обличчя» (Р. Темпл, М. Доркі, В. Амен), «Паровозик», «Який я?» (за О. Білобрикіною), проєктивна методика «Малюнок дерева», «Будиночок», «Графічний диктант». Ці методики були вибрані насамперед через те, що доступні для дітей. Вони привносять певний елемент гри в дослідження, що налаштовує дитину на позитивний лад, не дає їй нудьгувати і відволіктися. Також ці методики часто застосовуються психо- 
логами при дослідженні психологічних станів дітей. Тож їх ефективність доведена.

Методика «Вибери потрібне обличчя», розроблена Р. Темплом, М. Доркі та В. Аменом [9, с. 19], виявляє рівень тривожності у дітей старшого дошкільного віку.

Методика «Паровозик» $[9$, с. 36] оцінює позитивний та негативний психічні стани досліджуваного. Дитині пропонується до білого поїзда розставити кольорові вагончики один за одним. Послідовність цих вагонів і визначає позитивний та негативний стани.

Методика «Який я?» [9, с. 50] визначає емоційну спрямованість загальної самооцінки дитини. Малюк має вибрати одне із семи тверджень, які, на його думку, найкраще його описують.

Вибрана відповідь співвідноситься із рівнем самооцінки дитини. Так, соціально бажаною вважається позитивна самооцінка, нейтральний емоційний знак свідчить про несформованість почуття самооцінки, негативний - втрата почуття індивідуальної цінності, індиферентний - відсутність ціннісних орієнтирів, амбівалентний - неможливість соціокультурного самовизначення дитини.

Проєктивна методика «Малюнок дерева» [9, с. 101] виявляє емоційні та особистісні особливості малюка. Завдяки їй можна простежити ставлення дитини до себе, іiі самооцінку, характер взаємовідносин із оточенням, особистісні потреби. Дитина має намалювати дерево, яке їй подобається. При цьому жодних підказок робити не можна. При інтерпретації результатів береться до уваги стовбур, гілля, корінь, листя, розмір дерева, його розміщення на аркуші, дупло тощо. На основі отриманого малюнка складається психодіагностичний автопортрет дитини.

«Графічний диктант» [9, с. 42] дає змогу простежити рівень сформованості вольових зусиль дитини, вміння уважно слухати, точно виконувати вказівки дорослого.

Методика «Будиночок» виявляє уміння дитини орієнтуватися у своїй роботі за зразком, оцінити рівень розвитку довільної поведінки та уваги. Перед малюком ставиться зображення будиночка й пропонується точно його відтворити. Інтерпретація результатів здійснюється на основі зображення всіх частин будиночка. Окрім цього, було проведено кореляційний та порівняльний аналізи емпіричних даних.

Результати дослідження. Результати методики «Вибери потрібне обличчя» засвідчили, що у контрольній групі 43,3 \% дітей мають низький та середній рівні тривожності, 13,4 \% - високий; у дітей з дислалією - 9 \% низький, 36,6\% - середній, 56,4 \% - високий. Отже, як бачимо, у дітей 3 дислалією спостерігаються вищі показники тривожної симптоматики, ніж у дітей із нормотиповим мовленням. Однак такі дані можуть бути зумовлені особливістю вибірки, зокрема малою кількістю обстежуваних дітей 3 дислалією. Перевіривши ці дані за іншими методиками, отримуємо такі результати.

Методика «Паровозик» засвідчила такі особливості психічних станів дітей дошкільного віку: у контрольній групі у всіх нормотипових дітей - позитивний психічний стан; а 3 дислалією 45,4 \% - позитивний, 27,3 \% - низький негативний, 27,3 \% - середній негативний. Отже, як бачимо, у дітей із дислалією спостерігається негативний психічний стан, а у всіх дітей із нормотиповим мовленням - позитивний.

Методика «Який я?» констатувала, що у контрольній групі позитивну самооцінку мають 66,7 \% нормотипових дітей, нейтральну $26,6 \%$, амбівалентну - 6,7 \%. У дітей 3 дислалією у $36,4 \%$ - позитивна самооцінка, 54,6 \% - амбівалентна. Враховуючи отримані результати методики, можна стверджувати, що діти з дислалією на момент обстеження ще не самовизначилися.

Методика «Будиночок» констатувала рівень розвитку довільної поведінки та уваги. Так, у контрольній групі 40 \% нормотипових дітей мають високий рівень довільної поведінки та уваги, 53,3\% - достатній, 6,7 \% - середній. Натомість з дислалією 27,3 \% - достатній, 63,7 \% - середній та $9 \%$ - низький рівень довільної поведінки та уваги.

За допомогою методики «Графічний диктант» було встановлено рівень сформованості вольових зусиль дитини, вміння уважно слухати, точно виконувати вказівки дорослого. Так, у контрольній групі 63,3 \% нормотипових дітей мають високий рівень сформованості вольових зусиль, $20 \%$ - середній та 16,7 \% - низький. Натомість у дітей із дислалією 27,3 \% - низький, 72,7\% - середній і в жодної дитини не спостерігається високий рівень сформованості вольових зусиль.

Це можна пояснити тим, що успішність виконання зазначених завдань залежить від рівня розвитку в дитини дрібної моторики. А оскільки порушення мовлення пов'язані 3 розвитком останньої, то це вплинуло й на результати, отримані в ході дослідження. Більшість параметрів за проєктивною методикою «Малюнок дерева» так само засвідчує знижені психологічні показники у дітей з дислалією, зокрема: емоційно забарвлене відчуття власної цінності та значущості, упевненість у собі, повнота життя, енергетичне багатство - 37 \% у дітей з дислалією, відповідно 63 \% у контрольній групі. Аналогічні показники свідчать про відсутність впевненості у собі, відчуття дитиною власної незначущості, непотрібності, та знижену загальну енергетику: $64 \%-$ у дітей 3 дислалією, при 36 \% у контрольній групі. Така ж тенденція у проявах переважання негативних емоцій, наявності тривожності, невротич- 
них страхів: $45 \%$ - у дітей з дислалією при $23 \%$ у контрольній групі відповідно.

Для здійснення коректив розвитку емоційновольової сфери у дітей дошкільного віку були використані конспекти з навчального посібника
«Загадковий світ емоцій» [9]. Внаслідок проведення занять отримано суттєво кращі результати самооцінки, психічного стану та тривожності, проте рівень сформованості вольових зусиль у дошкільників не змінився (табл. 1).

Таблиия 1

Результати коректив розвитку емоційно-вольової сфери у дітей дошкільного віку

\begin{tabular}{|c|c|c|}
\hline Шкала & До корекційних занять & Після корекційних занять \\
\hline Самооцінка & $\begin{array}{l}\text { Діти з нормотиповим мовленням: } \\
\quad \text { - позитивна - 66,7\%; } \\
\quad \text { - нейтральна }-26,6 \% \\
\quad \text { - амбівалентна }-6,7 \% . \\
\text { Діти з дислалією: } \\
\quad \text { - позитивна }-36,4 \% ; \\
\quad \text { - амбівалентна }-54,6 \% \\
\end{array}$ & $\begin{array}{l}\text { Діти з нормотиповим мовленням: } \\
\quad \text { - позитивна - 86,7\%; } \\
\quad \text { - нейтральна - 13,3\%; } \\
\text { Діти з дислалією: } \\
\quad \text { - позитивна - } 100 \%\end{array}$ \\
\hline Тривожність & $\begin{array}{l}\text { Діти з нормотиповим мовленням: } \\
\quad \text { - низький - 43,3\%; } \\
\text { - середній - 43,3\%; } \\
\text { - високий - 13,4\%. } \\
\text { Діти } з \text { дислалією: } \\
\quad \text { - низький - 9\%; } \\
\text { - середній - 36,6\%; } \\
\text { - високий - 54,4\% } \\
\end{array}$ & $\begin{array}{l}\text { Діти з нормотиповим мовленням: } \\
\quad \text { - низький }-70 \% ; \\
\text { - середній - 23,3\%; } \\
\text { - високий - 6,7\%. } \\
\text { Діти з дислалією: } \\
\quad \text { - низький - 63,7\%; } \\
\text { - середній - } 27,3 \% \\
\text { - високий - } 9 \% \\
\end{array}$ \\
\hline Психічний стан & $\begin{array}{l}\text { Діти } з \text { нормотиповим мовленням: } \\
\quad \text { - позитивний - } 100 \text { \%; } \\
\text { Діти } 3 \text { дислалією: } \\
\quad \text { - позитивний }-45,4 \% ; \\
\text { - негативний низький }-27,3 \% \text {; } \\
\text { - негативний середній }-27,3 \%\end{array}$ & $\begin{array}{l}\text { Діти з нормотиповим мовленням: } \\
\quad \text { - позитивний - } 100 \text { \%; } \\
\text { Діти } 3 \text { дислалією: } \\
\quad \text { - позитивний - 72,7 \%; } \\
\text { - негативний низький }-27,7 \%\end{array}$ \\
\hline
\end{tabular}

У ході проведення коректив простежується, що дібрані алгоритми і конспекти корективної практики зі старшими дошкільниками виявилися результативними для корекції саме емоційної сфери дітей. Проте для розвитку рівня сформованості вольової поведінки цього виявилося замало.
На основі отриманих емпіричних показників здійснено кореляційний та порівняльний аналізи емпіричних даних. Результати кореляційного аналізу представлені на кореляційній плеяді на рис. 1.

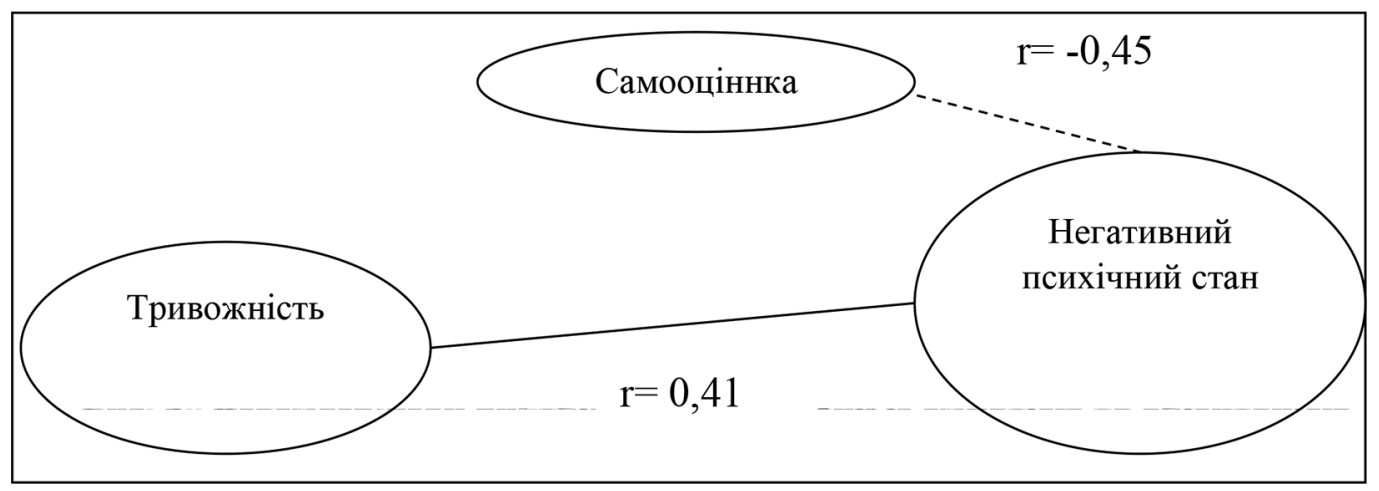

Puc. 1. Взаємозв’язок рівнів самооцінки, тривожності та негативного психічного стану в дітей з дислалією

Аналізуючи отриману кореляційну плеяду, простежуємо такі тенденції: 1) обернений помірний кореляційний зв'язок між негативним психічним станом та рівнем самооцінки, тобто при високому рівні самооцінки відповідно спостерігається низький рівень негативного психічного стану, що може доходити і до позитивного; 2) прямий помірний кореляційний зв'язок між негативним психічним станом та рівнем тривожності, що видно за параметрами, коли при високому рівні тривожності простежується негативний психічний стан дитини.

За допомогою порівняльного аналізу за U-критерієм Манна - Уітні у дітей з дислалією та нормотипових не виявлено значущих відмінностей за рівнем самооцінки, тривожності й негативного психічного стану. Це можна пояснити тим, що дислалія, як відносно не важке порушення мовлення, суттєво не впливає на емоційний тонус дошкільника. Попри те 
у дітей з дислалією, які мають високий рівень сформованості вольових зусиль, та в тих, хто має низький рівень їх сформованості, виявлені явні відмінності між рівнем тривожності (RankSum вис. $=30$, RankSum низ. $=36, p=0,014306)$ й негативним психічним станом (RankSum вис. = 30, RankSum низ. $=36, p=0,010580)$. У дітей із високим рівнем сформованості вольових зусиль суттєво нижчі рівні тривожності та негативного психічного стану. Це можна пояснити тим, що одним із симптомів тривожності є тремтіння рук, що ускладнює точне виконання методики, відповідно, і знижує шанси на досягнення високих результатів.

Висновки. У результаті дослідження встановлено, що дислалія, як відносно неважке порушення мовлення, суттєво не впливає на психологічні особливості дитини дошкільного віку. Проте задля уникнення подальшого ускладнення розвитку писемного мовлення у шкільному віці, а саме дислексії, дисграфії, потребує корекційної роботи та ранньої допомоги логопеда.

Емоційні неблагополуччя, зумовлені дислалією, негативно впливають на особистісний психічний стан і подальший розвиток дитини, тому вже в дошкільному віці потребує цільової корекції. Адже чим раніше вона розпочата, тим ефективніші будуть результати. Натомість порушення вольової сфери вважається нормою у такому віці, що пояснюється незрілістю зв'язків кори та підкірки головного мозку.

Дібрані конспекти для корекційної роботи зі старшими дошкільниками дають суттєві результати для корекції саме емоційної сфери дітей, проте практично безрезультатні при корекції вольової поведінки.

Перспективи подальших досліджень будуть спрямовані на пошук комплексних методик для отримання оптимального результату й відносно вольових параметрів у дітей з дислалією.

\section{ДЖЕРЕЛА}

1. Бєлова О.Б. Особливості розвитку когнітивних процесів та емоційно-вольової сфери у молодших школярів з ПМР. Актуальні питання корекційної освіти. 2012. Вип. 3. С. 297-305.

2. Валиева С.В. Диагностика психического состояния детей дошкольного возраста. СанктПетербург: Речь, 2007. 240 с.

3. Варій М.Й. Загальна психологія: підр. [для студ. вищ. навч. закл.]. [3-тє вид.]. К.: Центр учбової літератури, 2009. 1007 с.

4. Варій М.Й. Загальна психологія: навч. посіб. 2-ге вид., випр. і доп. К.: Центр учбової літератури, 2007. 968 c.

5. Вітенко І.С., Вітенко Т.І. Основи психології. Вид. 2-ге, доп. К.: Нова книга, 2008. 256 с.

6. Гиноян Р.В., Хомутов А.Е. Физиология эмоций. Нижний Новгород: Изд-во университета. 2010. $66 \mathrm{c.}$

7. Дерманова И.Б. Тест тревожности (Р. Тэммл, М. Дорки, В. Амен). Диагностика эмоциональнонравственного развития. Санкт-Петербург, 2002. 360 с.

8. Загальна психологія: підруч. / за заг. ред. С.Д. Максименка. Вінниця: Нова книга, 2004. 704 с.

9. Загадковий світ емоцій. Розвиток емоційної сфери дошкільників / упоряд. І.В. Молодушкіна. 2-ге вид. Х.: Вид. група «Основа», 2011. 207 с. [1]: іл. (Серія «Творчому педагогу»).

10. Конопляста С.Ю., Сак Т.В. Логопсихологія: навч. посіб.; за ред. М.К. Шеремет. К.: Знання, 2010. 293 c.

11. Кулешова O.В. Загальна та соціальна психологія URL: http://lubbook.net/book_225_glava_11_ Tema_8._Emo\%D1\%81\%D1\%96jjno-volova_sfe.html

12. Лапшин В.А., Пузанов Б.П. Основы дефектологии. Москва, 2000. 180 с.

13. Логопедия: учеб. для студ. дефект. фак. педвузов / под. ред. Л.С. Волковой, С.Н. Шаховской. Москва: ВЛАДОС, 2006. 680 с.

14. Логопедія: підруч. 2-ге вид. / за ред. М.К. Шеремет. К.: Видавничий Дім «Слово», 2013. 672 с.

15. Специальная педагогика: учеб. пособ. для студ. высш. учеб. завед. / Н.М. Назарова, Л.И. Аксенова, Б.А. Архипов, Л.И. Белякова и др.; под ред. Н.М. Назаровой. 4-е изд., стер. Москва: Изд. центр «Академия», 2005. 400 с.

16. Основы логопедической работы с детьми: учеб. пособ. для логопедов, воспитателей дет. садов, учителей нач. кл., студентов пед. училищ; под общ. ред. Г.В. Чиркиной. 2-е изд. испр. Москва: АРКТИ, 2003. $240 \mathrm{c.}$

17. Павелків Р.В., Цигипало О.П. Дитяча психологія: навч. посіб. для самост. роботи студ. К.: Академвидав, 2011. 373 с.

18. Психологія та патологія емоцій, волі, уваги: навч.-метод. посіб. для студ. 4-го курсу медичних факультетів зі спеціальностей «Лікувальна справа» та «Педіатрія». Запоріжжя, 2017. 72 с.

19. Психологічний словник / авт.-уклад. В.В. Синявський, О.П. Сергєєнкова / за ред. Н.А. Побірченко. К.: Науковий світ, 2007. 274 с. 
20. Соценко Т.М., Попович І.С. Особливості розвитку емоційно-вольової сфери у дітей дошкільного віку. Інсайт: зб. наук. праць студентів, аспірантів, та молодих вчених. Херсон: ВД «Гельветика», 2018. C. 243-246.

21. Тарапака Н.В., Кашуба Л.В. Інклюзія в дошкіллі: розвиток дітей із психофізичними вадами в умовах реалізації Базового компонента дошкільної освіти: навч.-метод. посіб. Кіровоград, 2013. $140 \mathrm{c}$.

\section{REFERENCES}

1. Bielova, O. B. (2012). Osoblyvosti rozvytku kohnityvnykh protsesiv ta emotsiino-voliovoi sfery u molodshykh shkoliariv z PMR. Aktualni pytannia korektsiinoi osvity, 2012, Vyp. 3, pp. 297-305 [in Ukrainian].

2. Valyeva S. V. (2007). Diagnostika psikhicheskogo sostoianiia detei doshkolnoho vozrasta. SPB.: Rech, 240 p. [in Russian].

3. Varii, M. Y. (2009). Zahalna psykholohiia.: pidr. [dlia stud. vyshch. navch. zakl.] 3-tie vyd., K.: Tsentr uchbovoi literatury, 1007 p. [in Ukrainian].

4. Varii, M. Y. (2007). Zahalna psykholohiia. Navchalnyi posibnyk. 2-he vydan., vypr. i dop., K.: Tsentr uchbovoi literatury, 968 p. [in Ukrainian].

5. Vitenko, I. S., Vitenko, T. I. (2008). Osnovy psykholohii. Vyd. 2, dopov., K.: Nova knyha, 256 p. [in Ukrainian].

6. Ginoian, R. V., Khomutov, A. E. (2010). Fiziologiia emotsii. Nizhnii Novgorod: Izd-vo universiteta, 66 p. [in Russian].

7. Dermanova, I. B. (2002). Test trevozhnosti (R.Temml, M. Dorky, V. Amen). Diagnostiyka emotsionalnonravstvennogo razvitiia. SPb., 360 p. [in Russian].

8. Zahalna psykholohiia. (2004). Za zah. red. S. D. Maksymenka, Vinnytsia: Nova knyha, 704 p. [in Ukrainian].

9. Zahadkovyi svit emotsii. Rozvytok emotsiinoi sfery doshkilnykiv (2011). Uporiad. I. V. Molodushkina, 2-he vyd., Kh.: Vyd. hrupa “Osnova”, 207, [1] p. : il. (Seriia “Tvorchomu pedahohu”) [in Ukrainian].

10. Konopliasta, S. Yu., Sak, T. V. (2010). Lohopsykholohiia: navch. posib., za red. M. K. Sheremet, K.: Znannia, 293 p. [in Ukrainian].

11. Kuleshova, O. V. Zahalna ta sotsialna psykholohiia [Elektronnyi resurs] [in Ukrainian]. http://lubbook.net/book_225_glava_11_Tema_8._Emo\%D1\%81\%D1\%96jjno-volova_sfe.html

12. Lapshin, V. A. (2000). Osnovy defektologii. M., 180 p. [in Russian].

13. Logopediia: Uchebnik dlia studentov defektologicheskogo fakulteta pedvuzov. (2006). Pod. red. L. S. Volkovoi, S. N. Shakhovskoi, M.: VLADOS, 680 p. [in Russian].

14. Lohopediia. (2003). Pidruchnyk, druhe vydannia. Za red. M. K. Sheremet, K.: Vydavnychyi Dim "Slovo", 672 p. [in Ukrainian].

15. Nazarova, N. M. (2005). Spetsialnaia pedagogika: ucheb. posobie dlia stud. vyssh. ucheb. zavedenii. L. I. Aksenova, B. A. Arkhipov, L. I. Beliakova i dr.; Pod red. N. M. Nazarovoi, 4-e izd., ster. M.: Izdatelskii tsentr "Akademiia", 400 p. [in Russian].

16. Osnovy logopedicheskoi raboty s detmi. (2003). Ucheb. posobie dlia logopedov, vospitatelei det. sadov, uchitelei nach. kl., studentov ped. uchilishch; Pod obshch. red. G. V. Chirkinoi, 2-e izd. ispr., M.: ARKTI, 240 p. [in Russian].

17. Pavelkiv, R. V. Dytiacha psykholohiia. (2011). Navch. posib. dlia samost. roboty stud., K.: Akademvydav, 373 p. [in Ukrainian].

18. Psykholohiia ta patolohiia emotsii, voli, uvahy. (2017). Navchalno-metodychnyi posibnyk dlia studentiv 4 kursu medychnykh fakultetiv zi spetsialnostei "Likuvalna sprava" ta "Pediatriia", Zaporizhzhia, 72 p. [in Ukrainian].

19. Psykholohichnyi slovnyk. (2007). Avt.-uklad. V. V. Syniavskyi, O. P. Serhieienkova, za red. N. A. Pobirchenko. K.: Naukovyi svit, 274 p. [in Ukrainian].

20. Sotsenko, T. M., Popovych, I. S. (2018). Osoblyvosti rozvytku emotsiino-volovoi sfery u ditei doshkilnoho viku. Insait: zb. nauk. prats studentiv, aspirantiv, ta molodykh vchenykh, Kherson: VD "Helvetyka" [in Ukrainian].

21. Tarapaka, N. V., Kashuba, L. V. (2013). Inkliuziia v doshkilli: rozvytok ditei iz psykhofizychnymy vadamy v umovakh realizatsii Bazovoho komponenta doshkilnoi osvity: navchalno-metodychnyi posibnyk, Kirovohrad, 140 p. [in Ukrainian]. 


\section{Сулятицкий И., Порохнявая А. ЭМОЦИОНАЛЬНО-ВОЛЕВЫЕ ОСОБЕННОСТИ ДОШКОЛЬНИКОВ С ДИСЛАЛИЕЙ}

В статье сделан анализ теоретических основ и эмпирических взаимосвязей между эмоциональноволевыми особенностями и речевым нарушением (дислалией) у детей дошкольного возраста. Обобщены исследования эмоционально-волевой сферы дошкольников с дислалией и дошкольников, у которых нет речевых отклонений. По результатам эмпирического исследования на основании установленных связей между уровнем развития эмоционально-волевой сферы и нарушениями речи у детей дошкольного возраста определены благоприятные факторы эффективных коррекционных приемов восстановления нормативных эмоционально-волевых параметров возрастной динамики удетей.

Ключевые слова: эмоции, воля, дислалия, речь, общее недоразвитие речи, нерезко выраженное недоразвитие речи, фонетическое недоразвитие речи, фонетико-фонематическое недоразвитие речи.

\section{Sulyatytskyy, A. Porokniava \\ EMOTIONAL-VOLITIONAL PECULIARITIES OF PRESCHOOL CHILDREN WITH DYSLALLIA}

The article analyses a theoretical basis and empirical relationships between emotional-volitional sphere and children's speech disorders (dyslallia). The article examines emotional-volitional sphere in preschool children with dyslallia and pre-school children with normal speech. Research results define the relationship between the level of development of the emotional-volitional sphere and speech disorders in preschool children. Also they reveal parameters of effective corrective methods of restoring normal emotional-volitional parameters preschool age dynamics.

In this article it is noticed that in preschool age actively formed personality, so it is necessary to make a maximum effort to prevent and overcome negative phenomenon that accompany the development of personality even in early childhood, because the earlier the assistance was provided the better the results will be.

In particular, it is said that the formation of speech is one of the most important components of harmonious child's personality. Its atypical development can lead to incorrect pronunciation and, at more complex disorders, can lead disorders in many mental structures: thinking, memory, attention and emotional-volitional sphere, of course.

In this article the authors had a goal to determine peculiarity of emotional-volitional sphere in preschool children with dyslallia. Among the tasks that must be performed to achieve the goal, the main ones are: theoretical analysis of scientific works on this issue; realization an empirical study of specifics emotional-volitional processes in preschooler with dyslallia and definition of relationships between the level of development of emotional-volitional sphere and speech disorders in preschool children.

Key words: emotion, will, dyslallia, speech, general lack of speech, poorly expressed undeveloped speech, phonetic underdevelopment of speech, phonetic and phonemic undevelopment of speech.

Стаття надійшла до редакції 11.03.2021 р.

Прийнято до друку 21.03.2021 p. 